NBER WORKING PAPER SERIES

THE IMPACT OF THE CIVIL WAR ON SOUTHERN WEALTH HOLDERS

\author{
Brandon Dupont \\ Joshua Rosenbloom \\ Working Paper 22184 \\ http://www.nber.org/papers/w22184
}

\author{
NATIONAL BUREAU OF ECONOMIC RESEARCH \\ 1050 Massachusetts Avenue \\ Cambridge, MA 02138 \\ April 2016
}

We are grateful for comments by participants at the 2015 annual conferences of the Western Economic Association, the Society for Economic Measurement, the Economic History Association, and the 2015 NBER Summer Institute. The views expressed herein are those of the authors and do not necessarily reflect the views of the National Bureau of Economic Research.

NBER working papers are circulated for discussion and comment purposes. They have not been peer-reviewed or been subject to the review by the NBER Board of Directors that accompanies official NBER publications.

(C) 2016 by Brandon Dupont and Joshua Rosenbloom. All rights reserved. Short sections of text, not to exceed two paragraphs, may be quoted without explicit permission provided that full credit, including $\odot$ notice, is given to the source. 
The Impact of the Civil War on Southern Wealth Holders

Brandon Dupont and Joshua Rosenbloom

NBER Working Paper No. 22184

April 2016

JEL No. N11,N31,N91

\begin{abstract}
$\underline{\text { ABSTRACT }}$
The U.S. Civil War and emancipation wiped out a substantial fraction of southern wealth. The prevailing view of most economic historians, however, is that the southern planter elite was able to retain its relative status despite these shocks. Previous studies have been hampered, however, by limits on the ability to link individuals between census years, and have been forced to focus on persistence within one or a few counties. Recent advances in electronic access to the Federal Census manuscripts now make it possible to link individuals without these constraints. We exploit the ability to search the full manuscript census to construct a sample that links top wealth holders in 1870 to their 1860 census records. Although there was an entrenched southern planter elite that retained their economic status, we find evidence that the turmoil of 1860 s opened greater opportunities for mobility in the South than was the case in the North, resulting in much greater turnover among wealthy southerners than among comparably wealthy northerners.
\end{abstract}

\author{
Brandon Dupont \\ Department of Economics \\ Western Washington University \\ Parks Hall 206B \\ 516 High Street \\ Bellingham, WA 98225 \\ brandon.dupont@wwu.edu \\ Joshua Rosenbloom \\ Economics Department \\ 266B Heady Hall \\ Iowa State University \\ Ames, IA 50011-1070 \\ and NBER \\ Jlrosenb@iastate.edu
}




\section{The Impact of the Civil War on Southern Wealth Holders}

Brandon Dupont and Joshua Rosenbloom

The U.S. Civil War and emancipation wiped out a substantial fraction of southern wealth. The prevailing view of most economic historians, however, is that the southern planter elite was able to retain its relative status despite these shocks. Previous studies have been hampered, however, by limits on the ability to link individuals between census years, and have been forced to focus on persistence within one or a few counties. Recent advances in electronic access to the Federal Census manuscripts now make it possible to link individuals without these constraints. We exploit the ability to search the full manuscript census to construct a sample that links top wealth holders in 1870 to their 1860 census records. Although there was an entrenched southern planter elite that retained their economic status, we find evidence that the turmoil of 1860s opened greater opportunities for mobility in the South than was the case in the North, resulting in much greater turnover among wealthy southerners than among comparably wealthy northerners.

\section{Introduction}

The Civil War and emancipation represent major turning points in the history of the United States. For scholars seeking to understand the consequences of the war, a central question has been whether the southern economic elite was able to retain its status and economic influence after the war, or was displaced by wartime destruction and the end of slavery. Some early scholarship concluded that since the plantation system disappeared after 1867, the war must have uprooted the Southern planter elite. This idea seems to have originated in an 1881 article by Henry W. Grady, which was later cited by Hammond (1897) in his well-known history of the cotton industry, and persisted well into the twentieth century. Buck (1937, p. 145), for example, concludes that "The small, rich landowning aristocracy in whose interest so much of Southern energy had been expended was deprived of its privileged position." By this time, 
however, other scholars had begun to challenge the view that the war had displaced the antebellum elite. Shugg (1937), for example, concluded, from an examination of Louisiana tax records, that the plantation system was not destroyed by the war and that land ownership actually became more concentrated after the war. ${ }^{1}$

The most influential modern works on the subject are Jonathan Weiner's (1976, 1979) studies using census data for five Alabama counties. Using the manuscript census to trace the fortunes of the planter elite, Weiner found that 43 percent of the 236 largest landholders in the Alabama black belt in 1860 remained among the planter elite in 1870. Noting that this rate of persistence rate was quite close to the 47 percent that prevailed from 1850 to 1860 period, Weiner concluded that the evidence supported Shugg's view that the wealthy planter elite held a greater share of real estate value in those counties after the war than it had before. Ransom and Sutch (1977) concurred, arguing that landownership was quite stable even though the number of farms in the five cotton states increased by 52 percent between 1860 and 1870 , and that the percent of improved land over 100 acres fell from 81 percent in 1860 to 60 percent in $1870 .{ }^{2}$ In a parallel study using data from one Texas county, Campbell (1982) analyzed population persistence over the 1850 to 1880 period and concluded that the rate of geographical persistence was fairly high among planters of

\footnotetext{
${ }^{1}$ Interestingly, Woodward (1951) cited Shugg's observation that northern corporations purchased Louisiana sugar plantations in support of his argument that there was a revolution in land ownership after the war. However, as Wiener (1976) pointed out, Shugg also argued that there was no such change in ownership for the cotton plantations. According to Shugg (1968, p. 246), the available evidence on cotton plantations "argues against any sudden or sweeping overturn in ownership."
}

${ }^{2}$ See Ransom and Sutch (1977), Table 4.5, p. 71 
all sizes: 43 percent of large planters persisted between 1860 and 1870, while poor whites were the least persistent (only a 22 percent persistence rate). He also found that while the planter elite suffered considerable economic losses during the Civil War decade, they actually improved their relative position between 1860 and 1880 . Ransom (1989, p. 234) similarly concluded that even though the large farms were broken up into smaller units, "land ownership in the South remained in the hands of those who had owned land and slaves before the war."

A crucial limitation of the work of Weiner, Campbell and others who have looked at the effect of the Civil War on the southern elite has been the restricted geographic scope of their analysis. On the one hand, this has meant assuming that results for one or a few counties can be safely generalized to apply to the region as a whole. On the other, given high rates of geographic mobility in the nineteenth century, it has not been possible to establish whether individuals who moved out of the area under study moved up or down, leaving open the possibility that any conclusions may reflect the vagaries of sample selection. ${ }^{3}$

Recent advances in electronic finding aids for historical censuses combined with online access to complete census manuscripts for the entire country, both available through the Ancestry.com website, allow us to improve on these earlier studies by examining the wealth persistence across the 1860s for a nationwide sample of individuals linked between 1860 and 1870 despite potential geographic mobility. In

${ }^{3}$ Given the high rates of geographic mobility of wealthy planters before the Civil War, there is good reason to be concerned about how to interpret the fate of those who moved out of a confined geographic area in the 1860s. According to Oakes (1982, p. 77), "nearly sixty percent of the 1850 slaveholders [in Jasper County, Georgia] were gone ten years later." Schaefer (1985) found similarly high rates of geographic mobility among slave owners between 1850 and 1860 . 
this article we analyze the origins of a sample of the wealthiest household heads in 1870 in both the South and the North. ${ }^{4}$ We find that although high levels of wealth provided a considerable cushion against the shocks of the Civil War decade, the 1860s were nonetheless characterized by a much higher degree of turnover among wealthy southerners than among comparably wealthy northerners. Conventional accounts are not wrong to emphasize the persistence of many wealthy southerners, but there is considerable evidence that the turmoil of the Civil War and emancipation opened greater opportunities for upward (and downward) mobility in the South than was the case in the North.

Before turning to a description and analysis of the linked data we begin, in the next section, with a brief introduction to the wealth data available in the Censuses of 1860 and 1870 and use these data to characterize the effects of the Civil War and emancipation on regional wealth holding. Section 3 describes our procedure for creating a linked sample beginning with high wealth individuals in 1870 and locating them in the 1860 census, and section 4 describes what these linked data reveal. We conclude with some additional interpretation of these results.

\section{The Impact of the Civil War on Wealth Levels and Distribution}

Both the 1860 and 1870 population censuses included questions about real and personal property ownership. Along with the 1850 census, which collected data on real property ownership, they constitute the only nationally representative data on

\footnotetext{
${ }^{4}$ Because of the small numbers of individuals in the Mountain and Pacific Census Divisions we exclude them from our analysis.
} 
personal wealth levels prior to the late- $20^{\text {th }}$ century. Wealth levels in both census years were self-reported, but a number of studies have confirmed their reliability. Soltow (1975, p. 6) found that reported wealth levels in the 1850 to 1870 censuses were "generally in line with estimates made by various authorities on wealth distribution. Growth rates are similar to those found for GNP per worker by Kuznets and commodity output per worker by Gallman." Steckel (1990) pointed out that real estate holdings cannot be easily concealed and were probably reliably reported. Even if respondents could have concealed their wealth, Querubin and Snyder (2011, p. 65) argued that they had no real incentives to do so because "even if some respondents were worried that the information provided would not in fact be confidential, there was no clear incentive for under-reporting or over-reporting wealth. There was no federal tax on wealth at the time, and no estate tax. Personal vanity, however, might have lead to some over-reporting." Steckel (1994) showed that discrepancies between local tax records and self-reported census wealth levels in Ohio and Massachusetts were not systematically related to other socioeconomic indicators for the period between 1820 and 1910. Galenson and Pope (1992, p. 227) also found that the selfreported census wealth was highly correlated with local tax rolls, and they concluded that "the wealth figures in the census manuscripts appear to be reasonably accurate estimates of household wealth, even though they may not typically have been based on detailed calculations of household wealth."

Although Census officials at the time and some later scholars have expressed concern about the quality of the 1870 census enumeration, arguing that there was significant under count in this year, more recent analysis suggests that these concerns 
are largely unfounded. ${ }^{5}$ According to Hacker et al (1999, p.129), "the undercount estimate given in the 1890 census report was greatly exaggerated as a result of a failure to account for the magnitude of the negative demographic shock caused by the Civil War. They point out that to arrive at the estimate of a 1.2 million person undercount, the 1890 investigators had assumed that the South experienced steady population growth between 1860 and 1880. Recent studies, however, have suggested that the Civil War substantially slowed population growth in the 1860 s relative to the pace in the 1870s. Adopting a more realistic set of assumptions about the rate of population increase in the 1860s implies an undercount of about 6.6 percent, not significantly different from nonresponse rates in modern survey data (Hacker, 2013). On this basis Hacker et al, argued that the "under enumeration of southern whites and blacks in 1870 was far lower than 1890 investigators estimated. [The 1870 census] will not pose a significant problem for most analyses." ${ }^{6}$ Whatever undercount issues exist with the 1870 census are, in any case, likely to be less relevant for the present study, since we focus on the top wealth holders whereas the undercount was most significant for poorer and younger blacks in the South.

Tables 1 and 2 summarize regional property ownership patterns by region in 1860 and 1870, respectively based on data available in the Integrated Public Use

${ }^{5}$ This concern originates with the Director of the 1870 Census, Francis Walker, who believed that there had been a significant undercount of the population. As a result of these concerns, President Grant ordered a recount in Philadelphia, New York, and Indianapolis. These concerns were reiterated in the 1890 census and have been accepted by many subsequent historians.

${ }^{6}$ Ransom and Sutch (1975) estimated that the black undercount was about 6.6 percent. 
Microdata Series (IPUMS) 1-in-100 random sample of the Census (Ruggles 2015). ${ }^{7}$

Because there are only a small number of observations from the Mountain and Pacific

Census divisions we have dropped these regions from our analysis. We further restrict

our sample to household heads. Since more than 90 percent of property ownership reported in the two censuses was attributed to household heads, inclusion of nonheads would simply increase the apparent inequity of the distribution without yielding additional insight. Within each region, we have sorted household heads by their percentile rank based on total property wealth. In the tables, we report a number of statistics characterizing property ownership by percentile groups. The first five rows of each table report the following values for each group: the number of observations in the IPUMS; median values for real property, personal property, and total property wealth; and the average share of real property in total wealth. The remaining rows report a number of demographic and occupational characteristics. The first column for each region shows characteristics of the bottom 55 percent of wealth holders. We selected this cut-off because the bottom 55 percent of household heads reported no real or personal property ownership in 1870 . The subsequent columns show characteristics for higher wealth groups.

The 1860 data illustrate in striking detail the enormous fortunes that the slave system permitted the wealthiest southerners to accumulate. The median wealth reported by those between the $99^{\text {th }}$ and $100^{\text {th }}$ percentile of southern wealth distribution in 1860 was a staggering $\$ 122,250$, more than three times the median wealth of the top 1 percent of northerners. Indeed, the median wealth of the richest

7 The North includes states in the Northeast and North Central Census division, while the South includes states in the South Atlantic and South Central Census divisions. 
northerners was comparable to the median for those between the $95^{\text {th }}$ and $99^{\text {th }}$ percentiles in the South. In an economy that was still predominantly rural and agricultural, slavery eliminated the labor constraints that limited the size of northern farms and allowed for a much greater concentration of wealth (Wright 1970, 1978; Ransom 1989). As Williamson and Cain (2010) put it, "The total estate for those in the upper tail of the [wealth] distribution was enormous. It should be emphasized, however, that this is not a small elite; as a group, slave owners were sizeable and wealthy."

The impact of slave wealth in the South is also apparent in the much lower share of real property in total wealth compared to the North. In the North, real estate was the principal vehicle of wealth accumulation, accounting for two-thirds or more of property ownership among the top 45 percent of wealth holders. In contrast, personal property (which included slaves) made up close to three-fifths of wealth in the top 10 percent of the Southern wealth distribution and was still about half of total property wealth for those between the $55^{\text {th }}$ and $90^{\text {th }}$ percentiles.

Comparing Table 2 with Table 1, it is evident how large an impact the Civil War and emancipation had on southern wealth holders. ${ }^{8}$ Given the prominent role of slaves among the property of the wealthiest southerners, it is reasonable to conjecture that the effects of emancipation may have been most pronounced at the top of the

\footnotetext{
${ }^{8}$ It is worth noting that the war itself was enormously costly for the nation as a whole, but disproportionately so for the South. Goldin and Lewis (1975) estimated that the war cost $\$ 75$ per capita for the North and $\$ 451$ for the South. The human cost was also considerably higher: 2.8 percent of the South's population was killed in the war compared to 1.5 percent of the North's population (Goldin, 1980, p. 938).
} 
wealth distribution. ${ }^{9}$ While northern wealth holders above the $55^{\text {th }}$ percentile experienced an approximately 50 percent increase in property holding over the $1860 \mathrm{~s}$, the value of property owned by southerners fell by nearly 75 percent. The drop was especially pronounced for personal property; above the $90^{\text {th }}$ percentile, southern wealth holders experienced a 90 percent drop in the value of personal property, while real property wealth was cut approximately in half. As a result, after the war the relative shares of real and personal property in the South converged toward those in the North, with real property making up 60-70 percent of wealth, at least among the wealthier household heads.

Tables 1 and 2 also reveal a number of other notable regional differences over the decade. Women made up a relatively small share of household heads in both regions and in both census years. However, women represented a larger fraction of wealth holders in the South both before and after the Civil War, and there was a noticeable increase in the female share of heads of household among the poorest households after the war. In the South in 1860, 84.7 percent of households below the $55^{\text {th }}$ percentile of the wealth distribution had male heads, but that number dropped to only 79.6 percent in the 1870 census. We suspect this is driven by the presence of war widows in the South, where an estimated one out of five white men of military age died in the war. ${ }^{10}$

${ }^{9}$ The elimination of slave wealth also had dramatic implications for the economic institutions that emerged during Reconstruction. Since slaves could no longer be used as collateral to secure credit, the "pawn-shop economy" of the furnishing merchants stepped into the breach (Ransom and Sutch, 1977). Moreover, Wright (1986) argued that massive shift in the basis of southern wealth transformed wealthy southerners from "laborlords" to "landlords."

${ }^{10}$ For more on southern war widows, see Hacker et al (2010) and Faust (2004). 
In the North, the likelihood that an individual was living outside of his or her state of birth diminished as wealth levels increased. In both 1860 and 1870 close to two-thirds of northerners below the $55^{\text {th }}$ percentile were living outside their state of birth, a proportion that fell to around 50 percent at the top of the wealth distribution. In the South, geographic mobility was markedly lower among those at the bottom of the wealth distribution, and there is no clear relationship between wealth and geographic mobility. The proportion of high wealth household heads living outside their state of birth was roughly similar to that for lower wealth household heads.

In both regions, rural residents outnumbered urban dwellers, but residence patterns looked rather different across wealth strata. In the North, the percent urban followed an inverted-U pattern in both 1860 and 1870, with the rural shares lowest at the bottom and top of the wealth distribution. As Rosenbloom and Stutes (2008) noted in their analysis of 1870 wealth data, inequality increased with urbanization. There was, however, a noticeable decline in rural residents over the course of the decade at all wealth levels. This decline was especially pronounced among the wealthiest 1 percent of Northerners, where the proportion rural fell from 53.4 percent to 39.2 percent over the decade. The proportion rural was consistently higher in the South, and, there was little variation across the wealth distribution in 1860. By 1870, perhaps reflecting the beginnings of a shift away from agriculture as the source of regional wealth in the South, the top 1 percent of southern wealth holders were much more likely to be urban residents than was the case ten years earlier.

The bottom rows in each table report the occupational distribution within each wealth stratum using the IPUMS standardized 1950 occupational codes. Farmers 
dominated the top of the southern wealth distribution in both 1860 and 1870, but white-collar jobs were much more important at the top of the northern wealth distribution. There were some notable changes in occupational composition across the wealth distribution over the Civil War decade. Most notably, and consistent with the rise in urbanization among top wealth holders in the South, the share of farmers in the top two strata fell, while the numbers of professional \& technical and clerical \& managerial occupations rose.

\section{Creating a Linked Sample}

The cross-sectional evidence presented so far is sufficient to establish that there were important regional differences in wealth holding, and that the Civil War and emancipation produced large shocks to wealth holding, especially in the South. They cannot, however, reveal what happened to individuals during the 1860s. Were the wealthiest southerners able to retain their relative position in the wealth distribution despite the absolute loss of wealth during the 1860s? Or did the shock of the war and emancipation cause those at the top to fall down the wealth distribution and allow those further down to rise up? As our earlier review of the literature suggests, answers to these questions have varied over time and have been limited in their generality by data constraints. Resolving this question requires following the fortunes of individuals over the course of the decade. Past efforts to do this have focused on following individuals within a limited area; however, as we describe in this section, we are now able to construct a nationally representative linked sample that is not constrained to the geographically immobile. 
To explore the impact of the Civil War decade on individual fortunes, we have created a linked sample by starting with those at the top of the wealth distribution in each region (North and South) in 1870 and attempting to locate them in the 1860 census. As such, this approach answers the question: where did the wealthiest household heads in each region in 1870 come from? Working backward has the virtue that we do not have to contend with the problem of failure to link individuals because of mortality. ${ }^{11}$

To construct our linked sample, we used the IPUMS to identify household heads with total 1870 property holdings that placed them among the top 5 percent in each region. Since it is still necessary to hand-collect the linked data, we chose the top 5 percent to provide a large enough sample of linked individuals for regional differences to be visible, while keeping the data collection effort manageable. For 1870, the IPUMS has collected both a 1 percent random sample and a black oversample, referred to as the 1.2 percent sample. ${ }^{12}$ In hopes of increasing the size of our initial sample of wealthy individuals we have drawn them from the 1.2 percent sample. To increase the chances of linking backward we restricted our analysis to household heads 25 and older, and to avoid the distorting effects of wealth transfers in old age, we imposed an upper limit of 75 years. This procedure generated a sample of 4,419 household heads

\footnotetext{
${ }^{11}$ An alternative to the approach we have taken would be to begin with the wealthiest individuals in 1860 and link them forward. As with the backward linkage approach we have taken, this method would yield insight about the degree of turnover among the wealthiest households, but would in addition shed light on what happened to those at the top of the wealth distribution at the beginning of the decade.

${ }^{12}$ For 1860 and 1870 the IPUMS $1.2 \%$ sample includes an oversample of households containing one or more blacks. While non-black households are sampled to produce a 1-in-100 sample of the population, households with black members were sampled at a rate of 1 -in-50.
} 
$(2,520$ and in the North and 1,899 in the South) to be linked backward to the 1860 census.

We then searched for each of the individuals in our sample in the 1860 census using the Ancestry.com database based on first and last name, and year of birth calculated from reported age in $1870 . .^{13}$ The search engine on this site allows for variant spellings and provides a list of individuals ranked by the quality of the match to the information entered. To qualify as a link, the individual located in the 1860 census had to have approximately the same first and last names and a birth year within 2 years of that recorded in 1870. In cases where the linkage was ambiguous because there were multiple individuals meeting these criteria, we used place of birth to distinguish between the potential matches. If, at this point, there were still multiple potential matches we did not record a link. For each linked individual we noted several aspects of link quality, including whether the place of birth was the same in both censuses, and whether we were able to identify other household members in both censuses. We did not, however, use information about other household members to determine which links to record because of the potential sampling bias that this criterion would introduce.

The results of our search are summarized in Table 3. In total we were successful in linking 1,918 individuals, a success rate of 43 percent. Based on indicators of link quality, our confidence in the linkage process is quite high. In all but 51 cases, place of birth was identical in both censuses, and in 85 percent of cases we were able to find other household members (a spouse and/or child) that matched

${ }^{13} \underline{\mathrm{http}} / / / \mathrm{www} \cdot \mathrm{ancestry.com}$ 
across the two censuses. Our linkage rate appears to be considerably higher than other studies that have sought to link nineteenth century census records. Ferrie (1996), for example, reports a success rate of just under 20 percent when linking forward from the 1850 to the 1860 census. The relatively high rate of success in linking in our sample likely reflects the greater stability of high wealth individuals. Backward linkage also eliminates the negative effects of mortality on linkage. ${ }^{14}$ This is especially important in light of evidence that approximately 8 percent of white males between ages 13 and 43 (in 1860) died in the war. ${ }^{15}$

Table 3 also reports a number of characteristics of the linked and unlinked individuals. The final two columns of the table report differences in mean values between the linked and unlinked samples and their significance levels. It is apparent that a number of these characteristics differed significantly between the linked and unlinked individuals. Linked individuals were, on average, 4 years older than those we failed to link. This may be because of the difficulty of locating records for younger individuals in 1860, especially if they were living in households headed by others. They also reported higher levels of property ownership, were more likely to be living in their state of birth, and were less likely to be foreign born. In addition, there was a strong regional differential in the likelihood of linkage, with northerners more likely to be linked than southerners. In contrast to the association of a number of personal

14 One study that used a backward linkage approach similar to ours was Schaefer (1985). He also found a high linkage rate of approximately 50 percent between the 1860 and 1850 censuses.

15 The estimated death rate is from Vinovskis (1989, p. 38). Previous studies (Wiener, 1976; Campbell, 1982) have recognized death as a factor in non-persistence and typically look for potential heirs, but this approach is obviously limited in cases where there were no surviving heirs. 
characteristics with the likelihood of linkage, the overall occupational distributions across the linked and unlinked groups was quite similar: close to 40 percent of both groups were farmers and another quarter were in clerical and managerial positions.

It is worth noting that about 7 percent of the top wealth holders we identified in 1870 were women. While the potential for name changes means that it is more difficult generally to locate women across census years, we have attempted to do so here and, as Table 3 indicates, women were only slightly less likely to be linked than men in our sample. In measuring 1860 wealth for women recorded in 1870 as household heads, we have attributed to them the sum of any property attributed to them in 1860 and any property owned by their husband at that time.

\section{Assessing Wealth Mobility in the 1860s}

The decade of the 1860s was characterized by substantial economic disruptions in both northern and southern states. In the South, the war resulted in property destruction and ended with the emancipation of the slave population, wiping out the largest component of southern wealth. In the North, the interruption of cotton shipments affected the textile industry, while the demands of raising and supplying the Union Army created opportunities for enterprising businessmen. How did these events affect wealth holders in both regions? Were the effects of wartime disruptions more concentrated in the South? Or were southern wealth holders able to hold onto their economic power despite the significant reductions in total wealth caused by emancipation? 
As we have noted, during the 1860s average wealth levels decreased substantially in the South, but increased in the North. So it makes the most sense to consider the question of wealth stability in relative terms within each region. Table 4 summarizes information about transitions in wealth strata in each region over the decade of the 1860s. The rows of each table indicate the location in the 1860 wealth distribution, while columns correspond to 1870 wealth levels. To locate individuals in the 1860 wealth distribution we have used percentile cut-offs for total property ownership in each region calculated from the IPUMS 1 percent sample. In the lower panel of the table, we report the value of each cell as a percentage of the column total.

Comparing the two regions, it is apparent that there was considerably more turnover among the ranks of top southern wealth holders than among northern wealth holders. While more than half of the those in the top 5 percent of northern wealth holders had been in the same group in 1860 just one-third of top southern wealth holders in 1870 had enjoyed a similar status in 1860 . Roughly the same proportion of the top 5 percent in each region was drawn from the next stratum of wealth holders in 1860 (90 $90^{\text {th }}$ to $95^{\text {th }}$ percentile). On the other hand, our data suggest that the turmoil of the Civil War decade created much greater opportunities for those with moderate wealth in 1860 - between the $55^{\text {th }}$ and $90^{\text {th }}$ percentiles - to move up to the top of the wealth distribution. Nearly 40 percent of the wealthiest southerners in 1870 had been in this group in 1860 , compared to less than one quarter of the richest northerners.

One concern in interpreting the results in Table 4 is that they may be influenced by differences in sample composition across regions. As noted earlier, the probability of linkage varied systematically with a number of personal characteristics, and it is 
possible that these differences affected differences in measured persistence. To test this hypothesis, we report the results of estimating a probit regression where the dependent variable takes the value 1 if the individual was in the top 5 percent of their region's wealth holders in 1860, and zero if the individual moved up from outside the top 5 percent in 1860 . The first specification includes only a constant and a zero-one indicator variable for 1870 region of residence. The second specification adds a quadratic in age as well as indicators for foreign born and living in 1870 outside the individual's state of birth. In the final specification, we add indicators for whether the individual's household includes a spouse or child. While several of these variables are statistically significant, they have little impact on the magnitude of the 1870 region of residence on persistence among the top wealth holders. With or without demographic controls, the regression estimates imply that 1870 residence in the North increased the probability that a top wealth holder had been among the top 5 percent in 1860 by close to 20 percentage points.

In addition to wealth mobility, the data we have collected on top wealth holders in 1870 allow us to evaluate the geographic mobility of this elite group. Only a very few of these wealthy individuals migrated between regions in the 1860s: only 18 (5 percent) of top southern wealth holders and 9 (1.1 percent) of top northern wealth holders had lived in a different region 10 years earlier. As Table 6 shows, interstate migration was also relatively uncommon, but somewhat more likely in the South. Among top wealth holders in 1870, 12.5 percent of those in the South had moved across state lines in the previous decade, while the corresponding figure for the wealthiest northerners was 9.3 percent. 


\section{Conclusion}

For the United States the 1860s were a period of pronounced economic turmoil resulting from a major war and the politically imposed end of slavery. These shocks created huge economic losses in the South, but must also have offered opportunities to profit in the region for those adept enough to respond to changing conditions.

Similarly, economic shocks to the northern economy should have created opportunities to profit. In the aggregate, the events of the 1860 s resulted in substantial declines in measured wealth in the South and large increases in wealth holding in the North. Views about how this turmoil affected those at the top of the southern economy have differed. Beginning in the late nineteenth-century, historians emphasized the turnover in southern economic elites, arguing that the Civil War wiped out the planter class and created a new elite. More recently, however, scholarly views have shifted, arguing that persistence rates at the top were no different in the $1860 \mathrm{~s}$ than they had been in the more peaceful 1850s.

By using the Ancestry.com database we are able to improve on past efforts to link wealthy individuals across census years. Where previous studies have been confined to a few counties, we are able to study a random sample of wealthy individuals in all locations and link them across census years regardless of geographic mobility. Like previous scholars, we too find that there was considerable persistence among wealth southerners: 45 percent of those in the top 5 percent of property owners 1870 had been among the top 10 percent of property holders in 1860 . But the rate of persistence in the South was considerably lower than it was in the North over 
the decade of the 1860s. In the North, almost 61 percent of those in the top 5 percent of wealth holders in 1870 had begun the decade in the top 10 percent. Thus, while wealth provided insulation from the shocks of the 1860s, it was a less effective insulator in the South than in the North.

For those interested in the impact of the Civil War and emancipation on the economic development of the postbellum South, the results reported here require some revision of widely accepted views. While there was undoubtedly an entrenched southern elite that held onto economic status and power, it also appears that the $1860 \mathrm{~s}$ introduced considerably greater levels of turnover in the South than in other parts of the United States. Collection of additional data will be required to determine whether these regional differences existed in the 1850s as well, or if the Civil War was the cause of this difference.

More generally, our findings that the Civil War led to higher rates of wealth mobility in the South have salience for discussions of the dynamics of wealth and income inequality. Prompted in part by the well-publicized work of Thomas Piketty (2014), economists have evidenced a renewed interest in this topic recently. Piketty has argued that capitalist economies are characterized by long-run tendencies toward increasing concentration of wealth and income, but that in the twentieth century the forces of concentration were significantly obscured by the massive disruptions caused by the two World Wars and the Great Depression. A number of other studies have explored the long-run persistence of social and economic status. Clark (2014) makes use of differences in the frequency of family names among elite groups to argue that social status is highly persistent over long time periods. Long and Ferrie (2013), using 
linked census data for the Unites States to trace patterns of occupational mobility, concluded that rates of mobility have declined since the nineteenth century. But less attention has been devoted to the way in which economic and political shocks may affect the persistence of social status. The evidence presented here adds support for the view that major political shocks can disrupt the normal accumulation of assets and cause greater wealth mobility, at least among those on the losing end of these shocks. 


\section{Bibliography}

Buck, P. H. (1937). The Road to Reunion, 1865-1900. Boston: Little, Brown and Company.

Campbell, R. B. (1982, May). Population Persistence and Social Change in Nineteenth Century Texas: Harrison County, 1850-1880. The Journal of Southern History , 185-204. Clark, G. (2014). The Son Also Rises: Surnames and the History of Social Mobility. Princeton: Princeton University Press.

Faust, D. (2004). Mothers of Invention. Chapel Hill: University of North Carolina Press. Ferrie, J. P. (1996). A New Sample of Americans Linked from the 1850 Public Use Micro Sample of the Federal Census of Population to the 1860 Federal Census Manuscript Schedules. Historical Methods , 34, 141-156.

Ferrie, J. P. (1997). The Entry into the U.S. Labor Market of Antebellum European Immigrants, 1840-1860. Explorations in Economic History, 34 (3), 295-330.

Galenson, D. W., \& Pope, C. L. (1992). Precedence and Wealth: Evidence from Nineteenth-Century Utah. In C. Goldin, \& H. Rockoff, Strategic Factors in Nineteenth

Century American Economic History: A Volume to Honor Robert W. Fogel (pp. 225-241). Chicago: University of Chicago Press.

Goldin, C. D. (1980). War. In G. Porter, Encyclopedia of American Economic History (Vol. 3, pp. 935-57). New York: Charles Scribner's Sons.

Goldin, C. D., \& Lewis, F. (1975, June). The Economic Costs of the American Civil War:

Estimates and Implications. The Journal of Economic History , 299-326.

Grady, H. W. (1881). Cotton and Its Kingdom. Harper's New Monthly Magazine. Hacker, J. D. (2013). New Estimates of Census Coverage in the United States, 18501930. Social Science History , 71-101.

Hacker, J. D., Hilde, L., \& Jones, J. H. (2010). The Effect of the Civil War on Southern Marriage Patterns. The Journal of Southern History , 39-70.

Hacker, J. D., Ruggles, S., Foroughi, A. R., \& Sargent, W. L. (1999). Public Use Microdata Samples of the 1860 and 1870 U.S. Censuses of Population. Historical Methods: A Journal of Quantitative and Interdisciplinary History , 32 (3), 125-133.

Hammond, M. (1897). The Cotton Industry. New York: The Macmillan COmpany. Long, J., \& Ferrie, J. (2013, June). Intergenerational Occupational Mobility in Great Britain and the United States since 1850. The American Economic Review , 1108-37. Oakes, J. (1982). The Ruling Race: A History of American Slaveholders. New York: Knopf. Piketty, T. (2014). Capital in the Twenty-First Century. Cambridge: Harvard University Press.

Querubin, P., \& Snyder, J. M. (2011). The Control of Politicians in Normal Times and Times of Crisis: Wealth Accumulation by U.S. Congressmen, 1850-1880 The Control of Politicians in Normal Times and Times of Crisis: Wealth Accumulation by U.S. Congressmen, 1850-1880. NBER Working Paper (17634).

Ransom, R. L. (1989). Conflict and Compromise: The Political Economy of Slavery, Emancipation and the American Civil War. Cambridge University Press. 
Ransom, R. L., \& Sutch, R. (1977). One Kind of Freedom: The Economic Consequences of Emancipation. Cambridge: Cambridge University Press.

Schaefer, D. (1985). A Statistical Profile of Frontier and New South Migration, 18501860. Agricultural History , 563-578.

Shugg, R. (1968). Origins of Class Struggle in Louisiana. Baton Rouge: LSU Press.

Shugg, R. W. (1937, August). Survival of the Plantation System in Louisiana. The Journal of Southern History, 311-325.

Soltow, L. (1975). Men and Wealth in the United States 1850-1870. New Haven: Yale University Press.

Steckel, R. H. (1994). Census Manuscript Schedules Matched with Property Tax Lists. Historical Methods , 71-85.

Steckel, R. H. (1990). Poverty and Prosperity: A Longitudinal Study of Wealth Accumulation. Review of Economics and Statistics , 275-85.

Vinovskis, M. A. (1989, June). Have Social Historians Lost the Civil War? Some Preliminary Demographic Speculations. The Journal of American History, 34-58. Wiener, J. M. (1979). Class Structure and Economic Development in the American South, 1865-1955. American Historical Review , 970-992.

Wiener, J. M. (1976, Autumn). Planter Persistence and Social Change. The Journal of Interdisciplinary History , 235-260.

Wiener, J. M. (1978). Social Origins of the New South: Alabama, 1860-1885. Baton Rouge: LSU Press.

Woodward, C. V. (1951). Origins of the New South. Baton Rouge: LSU Press. Wright, G. (1970, January). 'Economic Democracy' and the Concentration of Agricultural Wealth in the Cotton South, 1850-1860. Agricultural History , 63-93. Wright, G. (1986). Old South, New South: Revolutions in the Southern Economy Since the Civil War. New York: Basic Books.

Wright, G. (1978). The Political Economy of the Cotton South: Households, Markets, and Wealth in the Nineteenth Century. New York: Norton. 
Table 1: 1860 Characteristics of Northerners and Southerners, by percentile

\begin{tabular}{|c|c|c|c|c|c|c|c|c|c|c|}
\hline & \multicolumn{10}{|c|}{ Wealth Percentiles in $1860,1 \%$ Sample } \\
\hline & \multicolumn{5}{|c|}{ North } & \multicolumn{5}{|c|}{ South } \\
\hline & Below 55th & 55th & 90th & 95th & 99th & Below 55th & 55th & 90th & 95th & 99th \\
\hline Number of Observations & 18,764 & 12,379 & 1,782 & 1,378 & 356 & 6,631 & 4,221 & 599 & 487 & 121 \\
\hline Real Property Wealth (Median, \$) & 0 & 1,600 & 6,000 & 10,000 & 27,860 & 0 & 1,500 & 6,250 & 12,800 & 50,000 \\
\hline Personal Property Wealth (Median, \$) & 100 & 500 & 1,205 & 2,612 & 10,812 & 100 & 1,200 & 11,305 & 25,000 & 70,000 \\
\hline Total Property Wealth (Median, \$) & 100 & 2,200 & 7,327 & 13,000 & 40,000 & 150 & 3,100 & 17,800 & 38,000 & 122,250 \\
\hline Real as Pct of Total Property Wealth & $28.4 \%$ & $71.6 \%$ & $76.3 \%$ & $71.9 \%$ & $67.6 \%$ & $23.4 \%$ & $52.1 \%$ & $40.5 \%$ & $38.0 \%$ & $44.9 \%$ \\
\hline Male & $89.2 \%$ & $93.9 \%$ & $94.9 \%$ & $94.2 \%$ & $93.3 \%$ & $84.7 \%$ & $89.9 \%$ & $90.8 \%$ & $90.1 \%$ & $94.2 \%$ \\
\hline Rural Resident & $65.1 \%$ & $84.7 \%$ & $85.6 \%$ & $76.2 \%$ & $53.4 \%$ & $82.1 \%$ & $92.2 \%$ & $90.3 \%$ & $88.9 \%$ & $85.1 \%$ \\
\hline Foreign Born & $41.4 \%$ & $20.2 \%$ & $11.3 \%$ & $10.7 \%$ & $16.3 \%$ & $14.3 \%$ & $6.0 \%$ & $4.8 \%$ & $3.7 \%$ & $5.8 \%$ \\
\hline Living Outside Birthstate & $68.5 \%$ & $58.6 \%$ & $48.8 \%$ & $50.6 \%$ & $55.9 \%$ & $48.7 \%$ & $49.8 \%$ & $45.2 \%$ & $50.5 \%$ & $50.4 \%$ \\
\hline White & $98.2 \%$ & $99.7 \%$ & $99.9 \%$ & $99.8 \%$ & $100.0 \%$ & $94.4 \%$ & $99.4 \%$ & $99.8 \%$ & $99.6 \%$ & $99.2 \%$ \\
\hline Professional \& Technical & $2.1 \%$ & $3.1 \%$ & $2.9 \%$ & $7.0 \%$ & $7.6 \%$ & $1.7 \%$ & $4.3 \%$ & $9.0 \%$ & $8.6 \%$ & $3.3 \%$ \\
\hline Farming & $22.4 \%$ & $61.8 \%$ & $68.5 \%$ & $55.9 \%$ & $30.3 \%$ & $39.1 \%$ & $69.5 \%$ & $68.6 \%$ & $70.6 \%$ & $76.9 \%$ \\
\hline Clerical\&Managerial & $4.4 \%$ & $7.7 \%$ & $11.8 \%$ & $19.7 \%$ & $35.4 \%$ & $3.0 \%$ & $6.8 \%$ & $11.4 \%$ & $12.7 \%$ & $14.0 \%$ \\
\hline Sales & $1.6 \%$ & $0.8 \%$ & $0.8 \%$ & $0.4 \%$ & $2.2 \%$ & $1.0 \%$ & $0.7 \%$ & $0.7 \%$ & $0.2 \%$ & $0.0 \%$ \\
\hline Craftsmen & $21.7 \%$ & $12.4 \%$ & $6.2 \%$ & $4.9 \%$ & $6.2 \%$ & $16.3 \%$ & $7.7 \%$ & $3.0 \%$ & $1.8 \%$ & $1.7 \%$ \\
\hline Operatives \& Kindred workers & $11.0 \%$ & $5.0 \%$ & $2.6 \%$ & $3.6 \%$ & $3.7 \%$ & $6.4 \%$ & $2.2 \%$ & $0.8 \%$ & $0.4 \%$ & $0.0 \%$ \\
\hline Service workers & $2.4 \%$ & $0.5 \%$ & $0.2 \%$ & $0.6 \%$ & $0.0 \%$ & $2.9 \%$ & $0.9 \%$ & $1.0 \%$ & $0.4 \%$ & $0.0 \%$ \\
\hline Laborers & $23.4 \%$ & $2.8 \%$ & $1.1 \%$ & $0.8 \%$ & $0.8 \%$ & $18.0 \%$ & $1.2 \%$ & $0.2 \%$ & $0.2 \%$ & $0.0 \%$ \\
\hline Non-Occupational & $11.0 \%$ & $6.0 \%$ & $6.0 \%$ & $7.0 \%$ & $13.8 \%$ & $11.7 \%$ & $6.8 \%$ & $5.3 \%$ & $4.9 \%$ & $4.1 \%$ \\
\hline
\end{tabular}


Table 2: 1870 Characteristics of Northerners and Southerners, by percentile

\begin{tabular}{|c|c|c|c|c|c|c|c|c|c|c|}
\hline & \multicolumn{10}{|c|}{ Wealth Percentiles in $1870,1 \%$ Sample } \\
\hline & \multicolumn{5}{|c|}{ North } & \multicolumn{5}{|c|}{ South } \\
\hline & Below 55th & 55th & 90th & 95th & 99th & Below 55th & 55th & 90th & 95th & 99th \\
\hline Number of Observations & 25,261 & 15,992 & 2,429 & 1,810 & 492 & 11,099 & 7,718 & 1,049 & 833 & 217 \\
\hline Real Property Wealth (Median, \$) & 0 & 2,400 & 8,000 & 15,000 & 40,000 & 0 & 380 & 3,000 & 7,300 & 25,000 \\
\hline Personal Property Wealth (Median, \$) & 100 & 650 & 2,000 & 3,500 & 20,000 & 0 & 300 & 1,000 & 2,000 & 6,442 \\
\hline Total Property Wealth (Median, \$) & 175 & 3,100 & 10,500 & 19,000 & 60,000 & 0 & 725 & 4,152 & 9,900 & 31,333 \\
\hline Real as Pct of Total Property Wealth & $34.4 \%$ & $73.1 \%$ & $75.9 \%$ & $73.3 \%$ & $63.8 \%$ & $8.7 \%$ & $45.6 \%$ & $69.4 \%$ & $73.6 \%$ & $72.4 \%$ \\
\hline Male & $88.1 \%$ & $92.7 \%$ & $94.9 \%$ & $94.4 \%$ & $92.3 \%$ & $79.6 \%$ & $89.1 \%$ & $91.9 \%$ & $90.6 \%$ & $90.8 \%$ \\
\hline Rural Resident & $60.6 \%$ & $79.6 \%$ & $79.7 \%$ & $67.0 \%$ & $39.2 \%$ & $85.2 \%$ & $90.7 \%$ & $85.3 \%$ & $83.9 \%$ & $67.7 \%$ \\
\hline Foreign Born & $40.8 \%$ & $28.6 \%$ & $19.3 \%$ & $17.2 \%$ & $17.3 \%$ & $6.5 \%$ & $7.5 \%$ & $12.1 \%$ & $10.3 \%$ & $11.5 \%$ \\
\hline Living Outside Birthstate & $67.9 \%$ & $62.5 \%$ & $55.8 \%$ & $51.1 \%$ & $51.4 \%$ & $39.3 \%$ & $46.5 \%$ & $43.9 \%$ & $40.8 \%$ & $47.9 \%$ \\
\hline White & $97.1 \%$ & $99.6 \%$ & $99.9 \%$ & $99.9 \%$ & $99.8 \%$ & $40.9 \%$ & $89.8 \%$ & $99.3 \%$ & $99.5 \%$ & $99.5 \%$ \\
\hline Professional \& Technical & $2.1 \%$ & $2.5 \%$ & $3.7 \%$ & $6.1 \%$ & $7.3 \%$ & $1.0 \%$ & $3.0 \%$ & $6.5 \%$ & $8.2 \%$ & $8.8 \%$ \\
\hline Farming & $20.5 \%$ & $56.5 \%$ & $62.2 \%$ & $50.6 \%$ & $17.9 \%$ & $20.3 \%$ & $62.6 \%$ & $61.8 \%$ & $56.1 \%$ & $48.8 \%$ \\
\hline Clerical\&Managerial & $5.1 \%$ & $8.4 \%$ & $14.0 \%$ & $21.7 \%$ & $43.7 \%$ & $1.6 \%$ & $4.3 \%$ & $13.3 \%$ & $18.0 \%$ & $24.9 \%$ \\
\hline Sales & $1.8 \%$ & $1.3 \%$ & $1.2 \%$ & $1.4 \%$ & $2.6 \%$ & $0.6 \%$ & $0.6 \%$ & $0.5 \%$ & $0.6 \%$ & $0.5 \%$ \\
\hline Craftsmen & $18.6 \%$ & $12.4 \%$ & $6.1 \%$ & $5.0 \%$ & $5.1 \%$ & $7.3 \%$ & $7.9 \%$ & $5.5 \%$ & $5.0 \%$ & $4.1 \%$ \\
\hline Operatives \& Kindred workers & $14.4 \%$ & $5.8 \%$ & $2.6 \%$ & $3.1 \%$ & $3.0 \%$ & $4.0 \%$ & $3.1 \%$ & $2.0 \%$ & $1.0 \%$ & $1.4 \%$ \\
\hline Service workers & $2.2 \%$ & $0.6 \%$ & $0.4 \%$ & $0.3 \%$ & $0.4 \%$ & $3.8 \%$ & $0.9 \%$ & $0.6 \%$ & $0.5 \%$ & $0.0 \%$ \\
\hline Laborers & $23.5 \%$ & $4.1 \%$ & $1.3 \%$ & $0.9 \%$ & $0.6 \%$ & $45.9 \%$ & $8.0 \%$ & $0.9 \%$ & $0.5 \%$ & $0.0 \%$ \\
\hline Non-Occupational & $11.8 \%$ & $8.3 \%$ & $8.4 \%$ & $10.8 \%$ & $19.3 \%$ & $15.5 \%$ & $9.6 \%$ & $9.1 \%$ & $10.2 \%$ & $11.5 \%$ \\
\hline
\end{tabular}


Table 3: Characteristics of Backward Linked Sample

\begin{tabular}{|c|c|c|c|c|c|c|}
\hline & & \multicolumn{3}{|c|}{ Linked observations based on } & \multicolumn{2}{|c|}{ Difference in means } \\
\hline & & Name and & + & + & & \\
\hline & $\begin{array}{l}\text { No Link } \\
\text { (1) }\end{array}$ & $\begin{array}{l}\text { Age } \\
(2)\end{array}$ & $\begin{array}{c}\text { Birthplace } \\
\text { (3) }\end{array}$ & $\begin{array}{l}\text { HH Member } \\
\text { (4) }\end{array}$ & t-stat & $\begin{array}{l}\mathrm{P} \text { value of } \\
\text { difference }\end{array}$ \\
\hline Number of Observations & 2,501 & 1,918 & 1,867 & 1,623 & & \\
\hline \multicolumn{7}{|c|}{ Individual \& Household Characteristics: } \\
\hline Age & 47.5 & 51.5 & 51.4 & 52.5 & -11.79 & 0.0000 \\
\hline Nonwhite & $0.8 \%$ & $0.5 \%$ & $0.5 \%$ & $0.4 \%$ & 1.15 & 0.2511 \\
\hline North & $49.1 \%$ & $67.4 \%$ & $67.2 \%$ & $67.2 \%$ & -12.46 & 0.0000 \\
\hline Urban Resident & $68.9 \%$ & $70.4 \%$ & $70.5 \%$ & $71.1 \%$ & -1.08 & 0.2802 \\
\hline Male & $91.7 \%$ & $94.1 \%$ & $94.2 \%$ & $94.9 \%$ & -3.02 & 0.0025 \\
\hline Foreign Born & $16.4 \%$ & $10.5 \%$ & $10.6 \%$ & $10.7 \%$ & 5.78 & 0.0000 \\
\hline Has a Spouse in 1870 & $81.2 \%$ & $87.5 \%$ & $87.7 \%$ & $89.2 \%$ & -5.81 & 0.0000 \\
\hline Has a Child/Children in 1870 & $92.6 \%$ & $97.2 \%$ & $97.3 \%$ & $98.5 \%$ & -7.25 & 0.0000 \\
\hline Living Outside State of Birth & $50.1 \%$ & $44.0 \%$ & $44.1 \%$ & $44.5 \%$ & 4.09 & 0.0000 \\
\hline \multicolumn{7}{|l|}{ Wealth Levels: } \\
\hline Value of Real Property & $\$ 16,661$ & $\$ 21,153$ & $\$ 20,949$ & $\$ 21,015$ & -4.74 & 0.0000 \\
\hline Value of Personal Property & $\$ 7,937$ & $\$ 10,701$ & $\$ 10,387$ & $\$ 9,794$ & -3.09 & 0.0020 \\
\hline \multicolumn{7}{|l|}{ Occupations: } \\
\hline Professional \& Technical & $7.4 \%$ & $7.6 \%$ & $7.7 \%$ & $7.3 \%$ & -0.20 & 0.8385 \\
\hline Farming & $47.1 \%$ & $50.9 \%$ & $50.9 \%$ & $53.0 \%$ & -2.50 & 0.0126 \\
\hline Clerical\&Managerial & $24.2 \%$ & $21.5 \%$ & $21.4 \%$ & $20.4 \%$ & 2.13 & 0.0330 \\
\hline Sales & $1.0 \%$ & $1.4 \%$ & $1.3 \%$ & $1.3 \%$ & -0.95 & 0.3428 \\
\hline Craftsmen & $4.5 \%$ & $4.7 \%$ & $4.7 \%$ & $5.0 \%$ & -0.42 & 0.6763 \\
\hline Operatives \& Kindred workers & $2.2 \%$ & $2.3 \%$ & $2.4 \%$ & $2.5 \%$ & -0.32 & 0.7457 \\
\hline Service workers & $0.4 \%$ & $0.3 \%$ & $0.3 \%$ & $0.2 \%$ & 0.81 & 0.4178 \\
\hline Laborers & $0.9 \%$ & $0.5 \%$ & $0.5 \%$ & $0.6 \%$ & 1.58 & 0.1141 \\
\hline Non-Occupational & $12.3 \%$ & $10.8 \%$ & $10.8 \%$ & $9.9 \%$ & 1.48 & 0.1391 \\
\hline
\end{tabular}

*Statistically significant at *10\% level, **5\% level, and ***1\% level

T-tests for difference in means calculated using Welch's test when sample sizes and variances are unequal between groups. 
Table 4: 1860 Wealth of 1870 Top 5 Percent of Wealth Holders, by Region

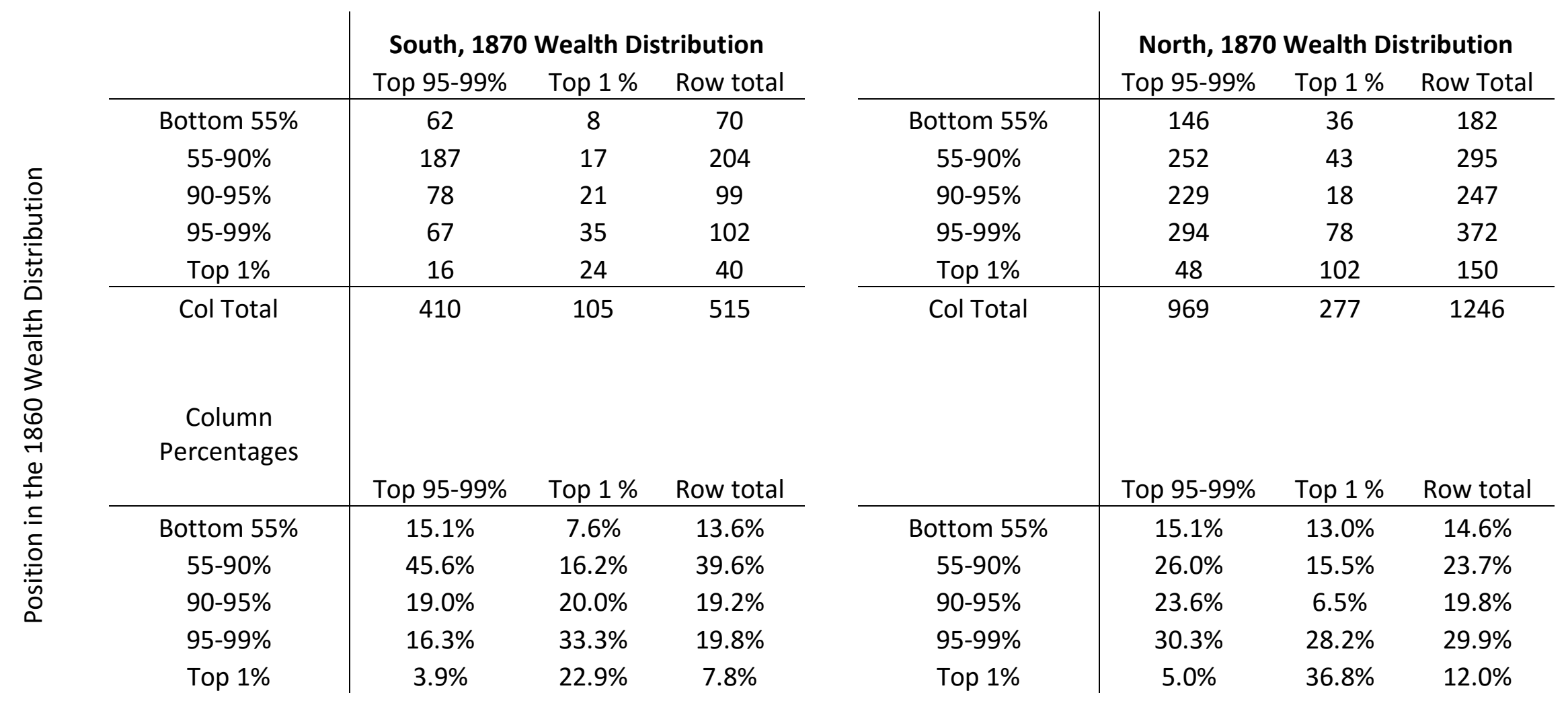

Source: Authors' calculation from observations of top wealth holders in 1870 linked to the 1860 population census. 
Table 5: Probit regressions for the probability that an individual in the top 5\% of 1870 wealth holders was among the top $10 \%$ of wealth holders in 1860
(1)
(2)
(3)

\begin{tabular}{|c|c|c|c|}
\hline North & $\begin{array}{c}\text { 0.211* } \\
(2.16)\end{array}$ & $\begin{array}{l}\mathbf{0 . 1 8 5} \\
(1.85)\end{array}$ & $\begin{array}{c}0.203^{*} \\
(2.03)\end{array}$ \\
\hline Age & & $\begin{array}{c}\mathbf{0 . 0 2 8 5} \\
(0.72)\end{array}$ & $\begin{array}{c}\mathbf{0 . 0 3 4 7} \\
(0.90)\end{array}$ \\
\hline Age squared & & $\begin{array}{c}-0.0000449 \\
(-0.12)\end{array}$ & $\begin{array}{c}-0.000109 \\
(-0.31)\end{array}$ \\
\hline Foreign Born & & $\begin{array}{c}-0.459 * * \\
(-2.65)\end{array}$ & $\begin{array}{c}-0.465 * * \\
(-2.68)\end{array}$ \\
\hline Lives Outside Birthstate & & $\begin{array}{r}0.0617 \\
(0.69)\end{array}$ & $\begin{array}{c}\mathbf{0 . 0 6 4 8} \\
(0.73)\end{array}$ \\
\hline
\end{tabular}

Has Spouse in 1870

$-0.118$

$(-0.86)$

Has Child in 1870

$-0.245$

$(-0.92)$

$\begin{array}{cccc}\text { Constant } & -1.412 * * * & -2.771 * * & -2.588 * \\ (-16.38) & (-2.60) & (-2.42)\end{array}$

\begin{tabular}{lccc}
\hline Number of Obs & 1761 & 1761 & 1761 \\
Pseudo R-Squared & 0.004 & 0.044 & 0.046 \\
Log Likelihood & -53155.9 & -51028.8 & -50888.3 \\
P-value & 0.0311 & $1.07 \mathrm{e}-08$ & $9.19 \mathrm{e}-09$
\end{tabular}

$* \mathrm{p}<0.05 \quad * * \mathrm{p}<0.01 \quad * * * \mathrm{p}<0.001$

Note: Marginal effects coefficients. Observations weighted by IPUMS hhwt variable. $\mathrm{T}$-statistics in parentheses. 
Table 6: Geographic Mobility of 1870 Top Wealth Holders

\begin{tabular}{|c|c|c|c|c|c|c|}
\hline \multirow[b]{3}{*}{ 1860/70 Residence } & \multicolumn{6}{|c|}{ Top 5 Percent of 1870 Wealth Holders } \\
\hline & \multicolumn{3}{|c|}{ South } & \multicolumn{3}{|c|}{ North } \\
\hline & $95-99 \%$ & Top 1\% & Row Total & $95-99 \%$ & Top 1\% & Row total \\
\hline Same state & 351 & 90 & 441 & 879 & 246 & 1,125 \\
\hline Different state & 59 & 16 & 75 & 91 & 31 & 122 \\
\hline \multirow[t]{4}{*}{ Column Total } & 410 & 106 & 516 & 970 & 277 & 1,247 \\
\hline & \multicolumn{6}{|c|}{ Column Percentages } \\
\hline & \multicolumn{3}{|c|}{ South } & \multicolumn{3}{|c|}{ North } \\
\hline & $95-99 \%$ & Top 1\% & Row total & $95-99 \%$ & Top 1\% & Row total \\
\hline Same state & $85.6 \%$ & $84.9 \%$ & $85.5 \%$ & $90.6 \%$ & $88.8 \%$ & $90.2 \%$ \\
\hline Different state & $14.4 \%$ & $15.1 \%$ & $14.5 \%$ & $9.4 \%$ & $11.2 \%$ & $9.8 \%$ \\
\hline
\end{tabular}

